\title{
Phonological Adaptation of Arabic Loanwords in Sabzevari Persian: Metathesis and Vowel Epenthesis
}

\author{
Mufleh Salem Alqahtani \\ Department of English Language and Literature, College of Arts, King Saud University, King Khalid Rd, 11451, Riyadh, \\ Kingdom of Saudi Arabia \\ *Corresponding Author: mqahtani1@ksu.edu.sa
}

Copyright $\bigcirc 2018$ by authors, all rights reserved. Authors agree that this article remains permanently open access under the terms of the Creative Commons Attribution License 4.0 International License

\begin{abstract}
This paper discusses the role of metathesis and vowel epenthesis in Arabic loanword adaptation in Sabzevari, a Persian vernacular spoken in the Sabzevar area of Northeast Iran. This role is accounted for using the framework of Optimality Theory (OT). The purpose of this paper is to elaborate the extent to which metathesis and vowel epenthesis, as repair strategies, are used for adapting Arabic loanwords in Sabzevari in the light of OT. This study mainly relies on data taken from extant literature including books, articles and theses. In addition, some videos on YouTube peculiar to this dialect and its speakers are taken into consideration for verifying data already harvested from the literature. The conclusion of the paper is that metathesis and vowel epenthesis are motivated by word-final clusters in Arabic loanwords that constitute Reversal Sonority, as a manifestation of Sonority Sequencing Violation. Metathesis targets word-final clusters in Arabic loanwords of the forms /plosive+fricative/ and /fricative+lateral/ while word-final clusters in Arabic loanwords of the forms /fricative+ rhotic/, /stop+nasal/, /stop+ liquid/, /nasal+ rhotic/, /stop+ nasal/, and /fricative + nasal/ are not immune to vowel epenthesis. OT is shown in this study to be a framework which is capable of analysing metathesis and vowel epenthesis with regard to Arabic loanwords in Sabzevari.
\end{abstract}

Keywords Sabzevari Dialect, Arabic Loanwords, Metathesis, Vowel Epenthesis, OT

\section{Introduction}

Adaptation of loanwords is a phonological phenomenon found in many languages around the world. It mainly depends on using phonological strategies including phonemic substitution, vowel epenthesis and metathesis, among others. Phonemic substitution is motivated by inactive articulators in languages. For example, in Persian, according to Hashemi [8], a labio-dental fricative $/ \mathrm{v} /$ replaces the labio-velar glide $/ \mathrm{w} /$ in some Arabic loanwords since the consonant $/ \mathrm{w} /$ is inactive in Persian, e.g, /wazn/ 'weight' $\rightarrow /$ vazn/. Vowel epenthesis is permitted in languages where there are restrictions on syllable structures when dealing with the adaptation of loanwords from other languages (Uffmann $[19,20])$. Scholars including Cain [6], Park [16], Alkinlabi [2], Mwihaki [15], Uffmann [19,20], Kenstowicz [12], Adomako [1] and Repetti [18] state that vowel epenthesis is found in other languages including Yoruba, Kikuyu, Japanese, Samoan, Fijian, Akan and Shona for the sake of English loanword adaptation. The following examples illustrate this phenomenon:

Table 1. Vowel epenthesis in English loanwords

\begin{tabular}{|c|c|c|c|}
\hline $\begin{array}{c}\text { English } \\
\text { word }\end{array}$ & $\begin{array}{c}\text { English } \\
\text { loanword } \\
\text { adaptation }\end{array}$ & Language & Reference \\
\hline 'class' & kíláàsi & Yoruba & (Alkinlabi, 1993) \\
\hline 'glass' & ngirathi & Kikuyu & (Mwihaki, 2001) \\
\hline 'strike' & sutoraiku & Japanese & (Park,1987) \\
\hline 'scout' & sikauti & Samoan & (Cain, 1986) \\
\hline 'spinach' & sipiiniji & Fijian & (Kenstowicz, 2007) \\
\hline 'stop' & sutopu & Akan & (Admako, 2008) \\
\hline 'green' & gi.ri:ni & Shona & (Uffmann, 2002) \\
\hline
\end{tabular}

The languages listed in (1) above have restrictions on their syllable structures since they do not permit word-initial clusters plus single or complex codas. This is why vowel epenthesis is inserted internally and peripherally in order to comply with restrictions on their syllable structures, especially when adapting English loanwords with complex onsets and single codas.

According to As-Sammer [4], metathesis is provoked by the sequence of $/ \mathrm{n}, 1 /$ in English loanwords, e.g. /penəltt/ 'penalty' $\rightarrow$ /ba.lan.ti/ in Iraqi Arabic.

This paper aims to illuminate the extent to which metathesis and vowel epenthesis play a role or not in 
Arabic loanword adaptation in Sabzevari Persian with reference to OT as an analytical framework. To achieve this aim, two questions are addressed.

The first is to question the extent to which extant metathesis and vowel epenthesis play a role in Arabic loanword adaptation in Sabzevari. The second investigates how to account for metathesis and vowel epenthesis in Arabic loanwords in Sabzevari using OT.

The next section pertains to previous studies on phonological loanword adaptation in Persian. Following that is a section looking into the role of metathesis in Arabic loanword adaptation in Sabzevari. The fourth section offers illumination on the role of vowel epenthesis in Arabic loanwords in Sabzevari. The fifth is devoted to analysing metathesis and vowel epenthesis in Arabic loanwords in Sabzevari using OT through a unified set of OT constraints. This is followed by a conclusion, which gives a summary of the paper and its findings.

\section{Literature Review}

Phonological adaptation of loanwords in Persian has been investigated by scholars including Kambuziya and Hashemi [13], Jabbari, et al. [10], Farazandeh-pour and Kambuziya [7] and Hashemi [8]. Kambuziya and Hashemi [13], who conducted their study on Russian loanword adaptation in Persian in light of Optimality Theory (OT), agree that Russian words are adapted in Persian using three phonological processes including no palatalised consonants - phonemic substitution - vowel insertion and vowel prosthesis. Russian words with palatalised consonants are adapted in Persian by substituting these consonants with plain ones, e.g. /otiu/ 'iron' $\rightarrow$ / Po.tu/. Complex onsets in some Russian words are adapted in Persian using vowel prosthesis and vowel insertion, e.g. /sta kan/ 'cup' $\rightarrow$ /Pes.te.kan/and / $/ \mathrm{leb} /$

'bread' $\rightarrow / x$ elab/. Likewise, according to Jabbari, et al. [10] vowel insertion and prosthesis are used as repair strategies by Persian leaners to adapt English initial clusters. Vowel prosthesis is functionally used by Persian learners to adapt English words with word-initial clusters in English words with the forms of $/ \mathrm{s}+$ plosive/, $/ \mathrm{s}+$ lateral, and $/ \mathrm{s}+$ nasal/. The following examples illustrate this:

Table 2. Vowel insertion and prosthesis in adaptation of English words with initial clusters by Persian learners of English

\begin{tabular}{|c|c|c|c|}
\hline Word-initial cluster & \multicolumn{2}{|c|}{ English word } & Realisation \\
\hline /sp-/ & sport & /spo:rt/ & [?es.port] \\
\hline$/$ st- $/$ & stamp & /stæmp/ & [ㄹes.tamp] \\
\hline$/ \mathrm{sl}-/$ & slide & /slaid/ & [?es.layd] \\
\hline$/ \mathrm{sn}-/$ & snack & /snæk/ & [?es.nak] \\
\hline$/ \mathrm{sm}-1$ & Smith & $/ \mathrm{smi} \theta /$ & [?es.mit] \\
\hline
\end{tabular}

Vowel epenthesis is used by Persian leaners to adapt
English words with word-initial clusters of the forms /plosive+liquid/, /s+rhotic/ and /s+w/. The following are some examples:

Table 3. Internal vowel epenthesis in adaptation of English words with initial clusters by Persian Learners of English

\begin{tabular}{|c|c|c|}
\hline Word-initial cluster & English word & Realization \\
\hline$/ \mathrm{bl}-/$ & /blæk/ & [bé.lak] \\
\hline$/ \mathrm{kl}-/$ & /kla:s/ & [ke..las] \\
\hline$/ \mathrm{dr}-/$ & drawer /drava/ & [de.rav.er] \\
\hline$/ \mathrm{pl}-/$ & plaster /plæstə/ & [pe.las.ter] \\
\hline$/ \mathrm{tr}-1$ & /trein/ & [tẹ.ran] \\
\hline$/ \mathrm{sr}-1$ & Sri Lanka /srr.læy.kə/ & [se..ri.lan.kâ] \\
\hline$/ \mathrm{sw}-/$ & swanhild /swæn.hıld/ & [se.van.hild] \\
\hline
\end{tabular}

Farazandeh-pour and Kambuziya [7] focus on the adaptation of German loanwords in Persian, using OT as a framework. They state that word-initial clusters of German loanwords in Persian provoke vowel epenthesis which is mostly identical to the vowel of the second syllable, e.g. Blumberg / $/ \beta l u: m \beta 3: \gamma / \rightarrow$ /bu.lum.bej/. Hashemi [8] whose work is specific to the phonological adaptation of Arabic Loanwords in Persian concentrates on phonemic substitution as a phonological process used for the adaptation of Arabic loanwords in Persian, compared to vowel prosthesis and insertion. That work observes that places of articulation including the interdental, pharyngeal, and labio-velar are inactive in Persian. These places in Arabic loanwords are adapted in Persian through substituting them with the closest consonants in terms of place of articulation, e.g./mo.wa:.ðsib/ 'punctual' $\rightarrow$ /mo.va:.zib/.

Finally, repair strategies such as phonemic constitution, vowel prosthesis and vowel insertion are phonological processes used for phonological adaptation of German, Russian, English and Arabic loanwords in Persian. With respect to the scholars above, however, there is nothing that addresses how metathesis and vowel epenthesis play a role in phonological adaptation of Arabic loanwords in Sabzevari Persian. This study investigates the phonological adaptation of Arabic loanwords in Sabzevari Persian, using metathesis and vowel epenthesis as repair strategies, in light of OT. The next section is devoted to demonstrating the adaptation of Arabic loanwords in Sabzevari Persian using metathesis.

\section{The role of Metathesis in Arabic Loanword Adaptation in Sabzevari}

Metathesis is considered to be one of repair strategies used for phonological adaptation of Arabic loanwords in Sabzevari. This repair strategy targets some word-final clusters in Arabic loanwords of the forms /stop+fricative/ and /fricative+ lateral/ that violate the Sonority Sequencing 
Principle (SSP). The following are examples of metathesis in Arabic loanwords in Sabzevari:

Table 4. Metathesis in Arabic loanwords in Sabzevari Persian

\begin{tabular}{|c|c|c|c|}
\hline $\begin{array}{c}\text { Standard } \\
\text { Arabic }\end{array}$ & $\begin{array}{c}\text { Sabzevari } \\
\text { Persian input }\end{array}$ & $\begin{array}{c}\text { Sabzevari } \\
\text { Persian output }\end{array}$ & Gloss \\
\hline /вusl/ & /gusl/ & [guls] & 'ablution' \\
\hline$/ \mathrm{mi} \theta \mathrm{l} /$ & $/ \mathrm{mesl} /$ & [mels] & 'like' \\
\hline /qufl/ & /qofl/ & [qolf] & 'lock' \\
\hline$/ t^{\text {fifl}} / /$ & /tefl/ & [telf] & 'child' \\
\hline /hads/ & /hads/ & [hasd] & 'guess' \\
\hline$/$ nabd $^{\S} /$ & /nabz/ & {$[$ nazb] } & 'pulse' \\
\hline /katf/ & /katf/ & [kaft] & 'shoulder' \\
\hline
\end{tabular}

The members of word-final clusters (Table.4) undergo swapping - metathesis - in order to comply with SSP, since peripheral members are more sonorous than the preceding ones where sonority rises again in the coda position, which is sonority reversal. Below are sonority representations of Sabzevari Persian input and /guls/ as Sabzevari Persian output.

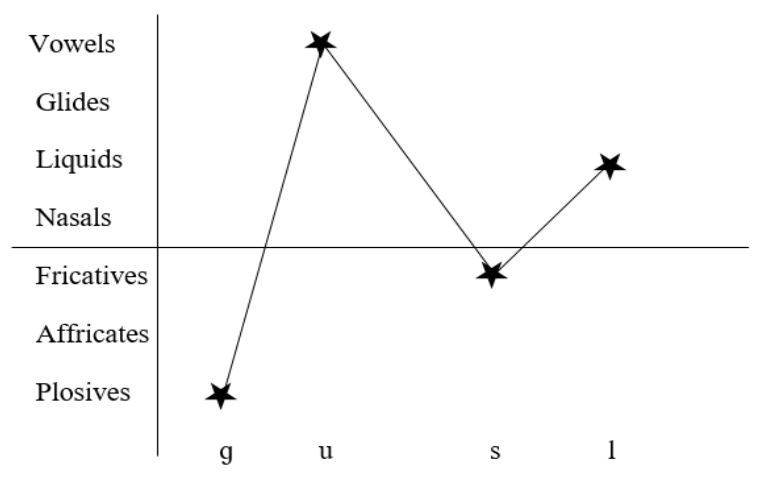

Figure 1. Sabzevari Persian input: /gusl/

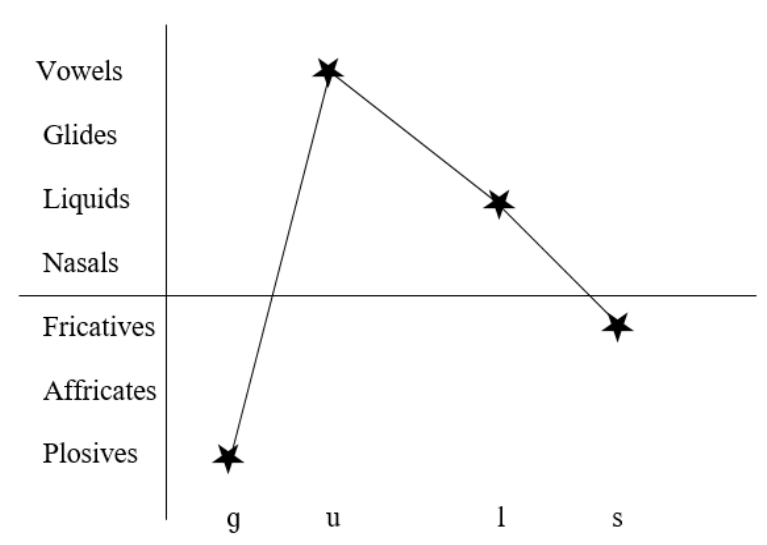

Figure 2. Sabzevari Persian output: [guls]
SSP violation in Arabic loanwords in Sabzevari is accounted for using OT. Consider the following OT

1)

a Syllable Contact (SYLLCON) Bat El [5] (p. 302): The onset of a syllable must be less sonorous than the last segment in the immediately preceding syllable and the greater the slope in sonority the better.

b CONTIG C-Fricative ${ }^{1}$ (Alqahtani [3])

An adjacent Consonant and Fricative sequence stand in correspondence in the input forming a contiguous string, as does the corresponding portion in the output.

c CONTIG C-Lateral (Alqahtani [3])

An adjacent Consonant and Lateral sequence standing in correspondence in the input form a contiguous string, as does the corresponding portion in the output.

d LINEARITY (McCarthy \& Prince [14]):

$\mathrm{S}_{1}$ reflects the precedence structure of $\mathrm{S}_{2}$, and vice versa.

e DEP-IO (McCarthy \& Prince [14]):

Every segment of $\mathrm{S}_{2}$ has a correspondent in $\mathrm{S}_{1}\left(\mathrm{~S}_{2}\right.$ is 'dependent on' $\mathrm{S}_{1}$ ).

f ${ }^{*}$ COMPLEX $_{\mathrm{COD}}$ (Prince and Smolensky [17]):

A syllable must not have more than one coda segment.

According to OT constraints in (1), *REVERSAL constraint is the most highly-ranked constraint in order to be against any candidates with sonority reversal. The SYLLCON is ranked lower than the *REVERSAL constraint which is functionally against candidates with rising sonority across syllable boundaries. The CONTIG C-Fricative is set against candidates that avoid violation of the SSP through vowel insertion between members of word-final clusters of the form /plosive + fricative/. The LINEARITY constraint which is subject to violation by any candidates with metathesis is ranked lower than The CONTIG C-Fricative. The DEP-IO constraint is outranked by the *COMPLEXCOD and is not satisfied with any type of epenthesis, either consonant or vowel epenthesis. The lowest ranked constraint is ${ }^{*}$ COMPLEX ${ }_{\mathrm{COD}}$ which is against complex codas.

The above set of OT constraints in (1) is provided to evaluate the candidates of the input/gusl/ 'ablution'.

1 CONTIG C-Fricative and CONTIG C-Lateral are derived from that introduced by Karim [11] (p.27), the CONTIG C-Stop. This constraint was developed through personal communication with Dr. Suzanne Urbanczyk. 
Table 5.

*REVERSAL $>>$ SYLLCON $>>$ CONTIG C-Fricative $>>$ CONTIG C-Lateral $>>$ LINEARITY $>>>>$ DEP-IO $>>*$ COMPLEX COD

\begin{tabular}{|c|c|c|c|c|c|c|c|}
\hline /gusl/ & $*$ REVERSAL & SYLLCON & $\begin{array}{c}\text { CONTIG } \\
\text { C-Fricative }\end{array}$ & CONTIG C-Lateral & LINEARITY & DEP-IO & $*$ COMPLEXCOD \\
\hline a. susl & $* !$ & & & & & & $*$ \\
\hline b. gusl & $* !$ & & & & & $*$ \\
\hline c. gr guls & & & & & $* !$ & & $*$ \\
\hline d. gu.sel & & & & & & $*$ & $*$ \\
\hline e. gus.le & & $* !$ & & & & $*$ \\
\hline
\end{tabular}

Candidate (c) in the table above is identified as the optimal candidate analysis for the input/susl/ since it satisfies constraints including *REVERSAL, SYLLCON and CONTIG C-Lateral. These constraints are also subject to violation by the rest of the candidates. For example, the REVERSAL constraint is violated by candidates (a) and (b) because these candidates have word-final clusters where sonority rises again in the coda position. Unlike candidates (a) and (b), candidates (d) and (e) avoid violation of the *REVERSAL through the permission of vowel epenthesis internally and peripherally. These candidates fail to be optimal, however, since they violate the SYLLCON and CONTIG C-Lateral constraints. The internal epenthesis in candidate (e) yields violation of the CONTIG C-Lateral constraint. That same constraint, CONTIG C-Lateral, is satisfied by candidate (e) through peripheral epenthesis which, by contrast, violates the SYLLCON constraint due to rising sonority across the syllable boundary. The same set of OT constraints in table (5) is used to evaluate the candidates of the input /nabz/ 'pulse'.

Table 6.

*REVERSAL $>>$ SYLLCON $>>$ CONTIG C-Fricative $>>$ CONTIG C-Lateral $>>$ LINEARITY $>>$ DEP-IO $>>*$ COMPLEX

\begin{tabular}{|c|c|c|c|c|c|c|c|}
\hline /nabz/ & $*$ REVERSAL & SYLLCON & $\begin{array}{c}\text { CONTIG } \\
\text { C-Fricative }\end{array}$ & CONTIG C-Lateral & LINEARITY & DEP-IO & $*$ COMPLEXCOD \\
\hline a. nabz & $* !$ & & & & & & $*$ \\
\hline b. . nazb & & & & & $*$ & & $*$ \\
\hline c. na.be z & & & $* !$ & & & $*$ & \\
\hline d. nab.ze & & $* !$ & & & & $*$ & \\
\hline
\end{tabular}

Table (6) identifies candidate (b) as optimal since it satisfies the *REVERSAL, SYLLCON, CONTIG C-Frictive, and LINEARITY constraints. Candidate (a) violates the *REVERSAL constraint since the marginal consonant has more sonority than for the one preceding where sonority rises again in the coda position. Candidate (c) successfully complies with the *REVERSAL constraint through internal epenthesis but this epenthesis prevents that candidate from being optimal due to a violation of the CONTIG C-Fricative constraint. Candidate (d) permits vowel epenthesis peripherally to avoid violation of the *REVERSAL and CONTIG C-Fricative constrains the site of vowel epenthesis which leads to sonority rising across the syllable boundary which consequently violates SYLLCON constraints.

To sum up, metathesis in Sabzevari is motivated by word-final clusters in Arabic loanwords in the forms /plosive+fricative/ and /fricative+lateral/. A special phenomenon in Arabic loanword adaptation in Persian relates to the word $/ \mathrm{nabd}^{\mathrm{q}} /$ where the word-final cluster forms the sonority plateau. The final consonant as an emphatic is changed to a voiced alveolar fricative in Sabzevari which results in sonority reversal. The word-final cluster then undergoes metathesis in order to satisfy SSP. The next section addresses vowel epenthesis in terms of Arabic loanword adaptation in Sabzevari. 


\section{The Role of Vowel Epenthesis in Arabic Loanword Adaptation in Sabzevari}

Vowel epenthesis is also used for Arabic loanword adaptation when dealing with Arabic words that have word-final clusters of the forms /fricative+ rhotic/, /stop+nasal/, /stop+ liquid/, /nasal+ rhotic/, /stop+ nasal/ and /fricative + nasal/. The outcome is that sonority reversal is yielded by word-final clusters in Arabic loanwords of the forms /fricative+ rhotic/, /stop+nasal/, /stop+ liquid/, /nasal+ rhotic/,/stop+ nasal/, and /fricative + nasal/ provokes vowel epenthesis in Sabzevari. The following examples illustrate this:

Table 7. Vowel epenthesis in Arabic loanwords in Sabzevari

I)

\begin{tabular}{|c|c|c|c|}
\hline $\begin{array}{c}\text { Standard } \\
\text { Arabic }\end{array}$ & $\begin{array}{c}\text { Sabzevari } \\
\text { Persian } \\
\text { intput }\end{array}$ & $\begin{array}{c}\text { Sabzevari } \\
\text { Persian } \\
\text { output }\end{array}$ & Gloss \\
\hline /ðৎuhr/ & /zohr/ & [zo.herr] & 'noon' \\
\hline /qahr/ & /qahr/ & [qa.herr] & 'subjugating' \\
\hline /wazn/ & /vazn/ & [va.zen] & 'weight' \\
\hline /rukn/ & /rokn/ & [ro.ken] & 'pillar' \\
\hline /fikr/ & /fekr/ & [fi.ker] & 'thinking' \\
\hline /sitr/ & /setr/ & [si.ter] & 'veil' \\
\hline$/ \operatorname{mis}^{\mathrm{\Upsilon}} \mathrm{r} /$ & /mesr/ & [me.ser] & 'Egypt' \\
\hline /husn/ & /hosn/ & [ho.sen] & 'goodness' \\
\hline /kufr/ & /kofr/ & [ko.fer $]$ & 'blasphemy' \\
\hline / $\mathrm{akk1} /$ & / $\mathrm{eek1/}$ & [Se.kel] & 'shape' \\
\hline /ficl/ & /fe?1/ & [fe.?리] & 'verb' \\
\hline$/ \mathrm{ji} \mathrm{r} \mathrm{r} /$ & $/ \mathrm{se} 2 \mathrm{r} /$ & 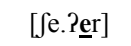 & 'poetry' \\
\hline$/ \mathrm{bat}^{\mathrm{S}} \mathrm{n} /$ & /batn/ & [ba.ten] & 'abdomen' \\
\hline /Sumr/ & /Pomr/ & [?o.mer] & 'life' \\
\hline /Guðr/ & /Pozr/ & [Po.zerer] & 'excuse' \\
\hline
\end{tabular}

II)

\begin{tabular}{|c|c|c|c|}
\hline / Pism/ & /Pesm/ & [?e.som] & 'name' \\
\hline /fahm/ & /fæhm/ & [fæ.hom] & 'understanding' \\
\hline$/ \mathrm{t}^{\mathrm{f}} \mathrm{a} \mathrm{m} /$ & $/ \mathrm{taPm} /$ & [ta.?om] & 'flavour' \\
\hline
\end{tabular}

In the examples in table (7), for the sake of SSP, reversal sonority found in the word-final clusters in Arabic loanwords in Sabzevari is solved by vowel epenthesis. The identity of vowel epenthesis is different, hence the epenthetic vowel [e] is used for adaptation of Arabic loanwords in (7-I) while the epenthetic vowel [o] is used for adapting Arabic loanwords in (7-II). Alqahtani [3] states that the identity of vowel epenthesis is determined by the following consonant by virtue of harmony. The epenthetic vowel should be harmonic to the second member of a word-final cluster with regard to any distinctive feature. For instance, the epenthetic vowel [e] is harmonic to the second members of word-final clusters in Arabic loanwords in (6-I) since they share the feature [+coronal]. Likewise, the epenthetic vowel [o] is harmonic to the second members of word-final clusters in Arabic loanwords in (6-II) because they share the feature [+labial]. The figure below provides sonority representations for Sabzevari Persian input/zohr/ and Sabzevari Persian output [zo.her].

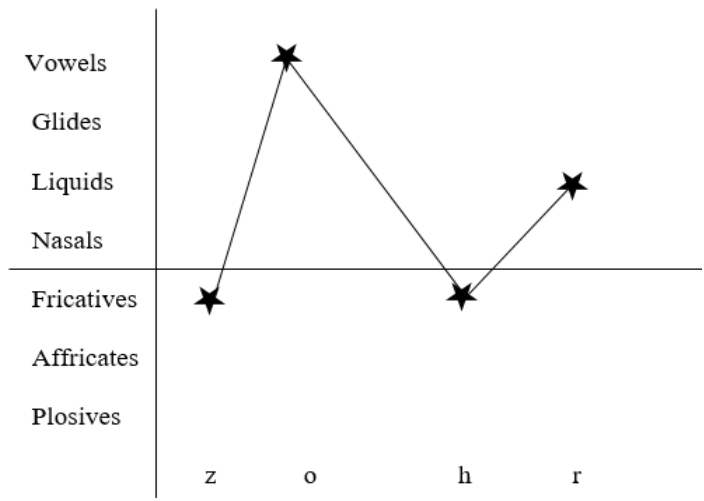

Figure 3. Sabzevari Persian input: /zohr/

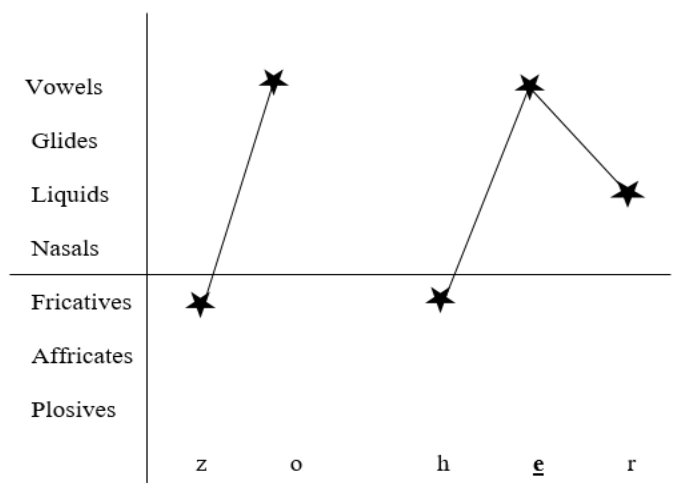

Figure 4. Sabzevari Persian output: [zo.her]

Vowel epenthesis in Arabic loanwords in Sabzevari is accounted for using OT. The tableau that follows is devoted to evaluating the candidates for the input/zohr/ 'noon'. 
Table 8.

*REVERSAL $>>$ SYLLCON $>>$ CONTIG C-Fricative $>>$ CONTIG C-Lateral $>>$ LINEARITY $>>$ DEP-IO $>>*$ COMPLEX ${ }_{\text {COD }}$

\begin{tabular}{|c|c|c|c|c|c|c|c|}
\hline /zohr/ & *REVERSAL & SYLLCON & $\begin{array}{c}\text { CONTIG } \\
\text { C-Fricative }\end{array}$ & $\begin{array}{l}\text { CONTIG } \\
\text { C-Lateral }\end{array}$ & LINEARITY & DEP-IO & ${ }^{*} \mathrm{COMPLEX}_{\mathrm{COD}}$ \\
\hline a. zohr & $* !$ & & & & & & $*$ \\
\hline b. zo.her & & & & & & $*$ & \\
\hline c. zorh & & & & & $* !$ & & $*$ \\
\hline d. zo.hür & & & & & & $*$ & \\
\hline e. zo.hin & & & & & & $*$ & \\
\hline
\end{tabular}

Table (8) fails to determine the optimal candidate of the input/zuhr/ since candidates (b), (d) and (e) all equally violate the DEP-IO. There should, therefore, be a constraint that helps identify candidate (b) as the optimal output and prevents candidates (d) and (e) from being optimal. The epenthetic vowels in candidates (d) and (e) are of the [+high] feature while that for candidate (b) is of [-high] feature. This means that the following constraint can solve this problem:

2)

DEP [+high] (Alqahtani [3])

A vowel that does not have an input correspondent must not be [+high].

The constraint in (2) will then be outranked in the DEP-IO constraint in order to eliminate candidates (d) and (e) from being optimal, as seen in the following tableau:

Table 9.

*REVERSAL $>>$ SYLLCON $>>$ CONTIG C-Fricative $>>$ CONTIG C-Lateral $>>$ LINEARITY $>>$ DEP [+high] $>>$ DEP-IO $>>*$ COMPLEX

\begin{tabular}{|c|c|c|c|c|c|c|c|c|}
\hline /zohr/ & *REVERSAL & SYLLCON & $\begin{array}{c}\text { CONTIG } \\
\text { C-Fricative }\end{array}$ & $\begin{array}{l}\text { CONTIG } \\
\text { C-Lateral }\end{array}$ & $\begin{array}{l}\text { LINEA } \\
\text { RITY }\end{array}$ & $\begin{array}{c}\text { DEP } \\
{[+ \text { high }]}\end{array}$ & DEP-IO & $\begin{array}{l}{ }^{*} \mathrm{COMPL} \\
\mathrm{EX}_{\mathrm{COD}}\end{array}$ \\
\hline a. zohr & $* !$ & & & & & & & $*$ \\
\hline b. zo.her & & & & & & & $*$ & \\
\hline c. zorh & & & & & $* !$ & & & $*$ \\
\hline d. zo.hur & & & & & & $* !$ & $*$ & \\
\hline e. zo.hị & & & & & & $* !$ & $*$ & \\
\hline
\end{tabular}

Table (9) successfully determines candidate (b) as the optimal candidate for the input /zohr/ since candidates (a), (c), (d), and (e) violate the *REVERSAL, LINEARITY, and DEP [+high] constraints. Candidate (a) violates the *REVERSAL constraint due to the word-final cluster which constitutes reversal sonority. The violation of that same constraint is avoided by candidate (c) through metathesis which results in violation of the LINEARITY constraint. Internal vowel epenthesis in candidates (d) and (e) avoids he violation of the *REVERSAL and LINEARITY constraints but fails to comply with the DEP [+ high] constraint. These candidates are therefore also eliminated from being optimal.

In conclusion, vowel epenthesis in Sabzevari is motivated by a sonority reversal found some word-final clusters in Arabic loanwords in this dialect in the forms of /fricative+ rhotic/, /stop+nasal/, /stop+ liquid/, /nasal+ rhotic/, /stop+ nasal/, and /fricative + nasal/. The identity of epenthetic vowels in Sabzevari is determined by the second member of a word-final cluster. For example, the epenthetic vowel [e] occurs when the second member of a word-final cluster is a coronal. This means that the epenthetic vowel [e] is harmony to the following consonant since both segments share the feature of [+coronal]. Likewise, the epenthetic vowel [o] is determined by the following consonant, which has the same feature as [+labial]. The next section sets out to highlight the unified set of OT constraints that analyse both metathesis and vowel epenthesis in Arabic loanwords in Sabzevari.

\section{A Unified Set of OT Constraints}

Metathesis and vowel epenthesis in Arabic loanwords in Sabzevari have been addressed in sections (3) and (4). This is in light of OT using different sets of OT constraints due to the addition of a new constraint, DEP [+high]. This can be seen in section (4). A unified set of OT constraints are used in this section to analyse vowel epenthesis and metathesis in terms of some Arabic loanwords in Sabzevari. 
Table 10.

*REVERSAL $>>$ SYLLCON $>>$ CONTIGC-Fricative $>>$ CONTIG C-Lateral $>>$ LINEARITY $>>$ DEP [+high] $>>$ DEP-IO $>>*$ COMPLEX $C O D$

\begin{tabular}{|c|c|c|c|c|c|c|c|c|}
\hline /gusl/ & *REVERSAL & SYLLCON & $\begin{array}{l}\text { CONTIG } \\
\text { C-Fricative }\end{array}$ & $\begin{array}{l}\text { CONTIG } \\
\text { C-Lateral }\end{array}$ & LINEARITY & DEP $[+$ high $]$ & DEP-IO & $\begin{array}{c}{ }^{*} \mathrm{COMPL} \\
\mathrm{EX}_{\mathrm{COD}}\end{array}$ \\
\hline а. вusl & $* !$ & & & & & & & \\
\hline b. gusl & $* !$ & & & & & & & \\
\hline c. guls & & & & & $*$ & & & \\
\hline d. gu.sel & & & & $* !$ & & & & $*$ \\
\hline e. gus.le & & $* !$ & & & & & & * \\
\hline /nabz/ & & & & & & & & \\
\hline a. nabz & $* !$ & & & & & & & \\
\hline b. nazb & & & & & $*$ & & & \\
\hline c. na.be $\underline{\text { z }}$ & & & $* !$ & & & & & $*$ \\
\hline e. nab.z므 & & $* !$ & & & & & & $*$ \\
\hline \multicolumn{9}{|l|}{ /zohr/ } \\
\hline a. zohr & $* !$ & & & & & & & $*$ \\
\hline b. zo.her & & & & & & & $*$ & \\
\hline c. zorh & & & & & $* !$ & & & $*$ \\
\hline d. zo.hür & & & & & & $* !$ & $*$ & \\
\hline e. zo.hịr & & & & & & $* !$ & $*$ & \\
\hline
\end{tabular}

\section{Conclusions}

This study has addressed the phonological adaptation of Arabic loanwords in Sabzevari through the use of two phonological processes; metathesis and vowel epenthesis. Metathesis is provoked by word-final clusters in Arabic loanwords of the forms /plosive+fricative/ and /fricative+lateral/ which constitute reversal sonority. Vowel epenthesis is motivated by word-final clusters in Arabic loanwords of the forms /fricative+ rhotic/, /stop+nasal/, /stop+ liquid/, /nasal+ rhotic/, /stop+ nasal/ and /fricative + nasal/ which form reversal sonority: The epenthetic vowels [e] and [o] are determined by peripheral members. The epenthetic vowel [e] shares the feature of [+coronal] with the following consonant, while the epenthetic vowel [o] shares the feature of [+labial] with the following consonant. Metathesis and vowel epenthesis in Arabic loanwords in Sabzevari are accounted for using a unified set of OT constraints which shows how OT, as a framework, is capable of addressing the phonological adaptation of Arabic loanwords in Sabzevari with reference to both metathesis and vowel epenthesis.

\section{Acknowledgements}

The researcher is very grateful to the Research Centre in the Faculty of Arts at King Saud University for funding this piece of research.

\section{REFERENCES}

[1] K. Adomako. Vowel epenthesis and consonant deletion in loanwords: a study of Akan, MA dissertation, University of Tromsø, 2008.

[2] A. Alkinlabi. Underspecification and the phonology of Yoruba/r, Linguistic Inquiry, 139-160, 1993

[3] M. Alqahtani. Sonority Sequencing Principle in Sabzevari Persian: A constraint-based Approach, Under review, (undated).

[4] M. As-Sammer. Phonetic and Phonological Adaptations of English Loanwords into Iraqi Arabic: A Generative Study, Journal of the College of Arts, University of Basra, 2015.

[5] O. Bat-El. Selecting the best of the worst: the grammar of Hebrew blends, Phonology, Vol. 13, No.3, 283-328, 1996.

[6] H. Cain. A lexicon of foreign loan-words in the Samoan language, Böhlau, 1986.

[7] F. Farazandeh-pour, A. Kord Zafaranlu Kambuziya. German Loanwords Adaptation in Persian: Optimality Approach, The International Journal of Humanities, Vol. 20 No. 4, 23-40, 2014.

[8] H. Fleischhacker. Cluster-dependent epenthesis asymmetries, In Papers in Phonology 5, eds. Adam Albright and Taehong Cho, 71-116, UCLA Working Papers in Linguistics, 2001

[9] E. S. Hashemi, Phonological Adaptation of Arabic Loan Words in Persian: Consonants. International Journal and Humanities and Social Science, Vol. 4, No. 6, 1, 2014.

[10] A. A. Jabbari, P. Safari, F. Falaknaz, J. V. D. Weijer. The 
Adaptation of English Initial Clusters by Persian Learners, Journal of Teaching Language Skills, Vol. 30, No. 4, 59-76, 2011.

[11] K. Karim. Vowel epenthesis in Bangla: An Optimality Theory analysis, Working Papers of the Linguistics Circle, Vol. 20 No.1, 26-36, 2010.

[12] M. Kenstowicz. Salience and similarity in loanword adaptation: a case study from Fijian, Language Sciences, Vol.29, No.2, 316-340, 2007.

[13] A. Kord Zafaranlu Kambuziya, E. S. Hashemi. Russian Loanword Adaptation in Persian; Optimal Approach, Iranian Journal of Applied Language Studies, Vol. 3, No. 1, 77-96, 2012

[14] J. J. McCarthy, A. Prince. Faithfulness and reduplicative identity, In J. Beckman, L. Dickey, and S. Urbanczyk (eds.). Papers in Optimality Theory, UMOP Vol. 18, 249-384, Amherst: GLSA, 1995.
[15] A. Mwihaki. Consonant-vowel harmony: Evidence from the phonotactics of loanword adaptation, Poznan Studies in Contemporary Linguistics, Vol. 37, 139-145, 2001

[16] W. Park. Western loan-words in Japanese. Stockholm University, Department of Oriental Languages, 1987.

[17] A. Prince, and P. Smolensky. Optimality Theory: Constraint interaction in generative grammar, MS, Rutgers University and University of Colorado, Boulder, 1993

[18] L. Repetti. Consonant-final loanwords and epenthetic vowels in Italian, Catalan Journal of Linguistics, Vol. 11, 167-188, 2012.

[19] C. Uffmann. A typology of epenthetic vowels in loanwords, Ms. Philipps-Universitat Marburg, 2002.

[20] C. Uffmann. Epenthetic vowel quality in loanwords: Empirical and formal issuesn, Lingua, Vol. 116, No.7, 2006. 